Article

\title{
Amoxicillin in Water: Insights into Relative Reactivity, Byproduct Formation, and Toxicological Interactions during Chlorination
}

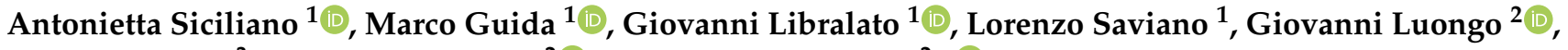 \\ Lucio Previtera $^{3}$, Giovanni Di Fabio ${ }^{2}$ (D) and Armando Zarrelli ${ }^{2, *(D)}$ \\ 1 Department of Biology, University of Naples Federico II, 80126 Naples, Italy; \\ antonietta.siciliano@unina.it (A.S.); marco.guida@unina.it (M.G.); giovanni.libralato@unina.it (G.L.); \\ lorenzosaviano@libero.it (L.S.) \\ 2 Department of Chemical Sciences, University of Naples Federico II, 80126 Naples, Italy; \\ giovanni.luongo@unina.it (G.L.); difabio@unina.it (G.D.F.) \\ 3 Associazione Italiana per la Promozione delle Ricerche su Ambiente e Salute umana, 82030 Dugenta, Italy; \\ previter@unina.it \\ * Correspondence: zarrelli@unina.it; Tel.: +39-08-167-4472
}

check for updates

Citation: Siciliano, A.; Guida, M.; Libralato, G.; Saviano, L.; Luongo, G.; Previtera, L.; Di Fabio, G.; Zarrelli, A. Amoxicillin in Water: Insights into Relative Reactivity, Byproduct Formation, and Toxicological Interactions during Chlorination. Appl. Sci. 2021, 11, 1076. https:// doi.org/10.3390/app11031076

Academic Editor: Panagiotis

G. Asteris

Received: 23 December 2020

Accepted: 21 January 2021

Published: 25 January 2021

Publisher's Note: MDPI stays neutral with regard to jurisdictional claims in published maps and institutional affiliations.

Copyright: (c) 2021 by the authors. Licensee MDPI, Basel, Switzerland. This article is an open access article distributed under the terms and conditions of the Creative Commons Attribution (CC BY) license (https:// creativecommons.org/licenses/by/ $4.0 /)$.

\begin{abstract}
In recent years, many studies have highlighted the consistent finding of amoxicillin in waters destined for wastewater treatment plants, in addition to superficial waters of rivers and lakes in both Europe and North America. In this paper, the amoxicillin degradation pathway was investigated by simulating the chlorination process normally used in a wastewater treatment plant to reduce similar emerging pollutants at three different $\mathrm{pH}$ values. The structures of 16 isolated degradation byproducts (DPs), one of which was isolated for the first time, were separated on a C-18 column via a gradient HPLC method. Combining mass spectrometry and nuclear magnetic resonance, we then compared commercial standards and justified a proposed formation mechanism beginning from the parent drug. Microbial growth inhibition bioassays with Escherichia coli, Klebsiella pneumoniae, and Staphylococcus aureus were performed to determine the potential loss of antibacterial activity in isolated degradation byproducts. An increase of antibacterial activity in the DPs was observed compared to the parent compound.
\end{abstract}

Keywords: amoxicillin; chlorination; hypochlorite; degradation by-products; water treatment; acute toxicity test; Daphnia magna

\section{Introduction}

The presence of pharmaceutical compounds in natural water bodies, even at low concentrations, raises health concerns. Pharmaceutical substances, used to prevent and fight diseases, are produced to guarantee their maximum effectiveness and, at the same time, ensure their resistance to inactivation until they perform their intended functions. Thus, these compounds can be excreted through feces and urine in the form of metabolite mixtures and their unchanged product, which flow into wastewater treatment plants (WWTPs). The recent widespread detection of these compounds in such environments [1-6] have led to their designation as emerging contaminants, as they are still unregulated. The environmental persistence and high biological activity that characterizes them make these substances harmful, even at low concentrations. These contaminants can, in fact, cause alterations to the endocrine system [7] and an increase in microbial resistance to drugs [8-11]. They can also be adsorbed by plants [12] and bioaccumulated [13] in the food chain. Additional risks are associated with biodiversity loss [7], infertility, and cancer $[14,15]$. One of the categories of drugs on which the attention of the scientific community is most focused is that of antibiotics present in the aquatic environment and in 
foods, which have the possibility of inducing the formation of antibiotic-resistant bacteria and the health risks that may derive from them $[16,17]$.

Amoxicillin (AMO) is among the most prescribed antibiotics for human use in Italy [18] and other European countries [19], which is a drug synthesized in large amounts and used in aquaculture farms to cope with the most common fish diseases. In Italy, it is estimated that more than $210 t$ are used annually, of which $86 \pm 8 \%$ [20] are excreted in parental form with a theoretical environmental load estimated at around $190 \mathrm{t} /$ year. Risk assessment studies for aquatic species and humans are under development, but despite the small amount of ecotoxicological data, some studies found it possible to establish compounds, such as AMO, in surface waters at non-negligible risk levels for aquatic species organisms [21,22].

AMO has been detected at $\mu \mathrm{g} / \mathrm{L}$ concentrations in the influent and effluent of WWTPs and surface water $[23,24]$, while its levels in pharmaceutical industry effluents may reach $\mathrm{mg} / \mathrm{L}$ concentrations [25].

Although the treatment processes used in the plants shows high AMO removals [26-28], even if the percentage of removal depends on the duration of the treatment [29], at the same time, they have the disadvantage of increasing effluent toxicity and producing its transformation compounds, which may be more toxic than the product from which they derive [30]. As a consequence, WWTP effluents and the practice of reusing sewage sludge in agriculture to recover nitrogen compounds useful for soil fertilization can contribute to its introduction into water bodies and its diffusion in the terrestrial environment of the degradation byproducts (DPs) of the drug [31-34]. Humans can be exposed to DPs through the consumption of aquatic organisms, agricultural products, or drinking water.

In this paper, DPs of AMO were investigated under the same conditions as the chlorination process normally used in WWTPs to reduce similar emerging pollutants $[35,36]$ at three different $\mathrm{pH}$ values. In particular, a chromatographic profile of the possible DPs was obtained with an experiment at low concentrations of AMO (about $10^{-5} \mathrm{M}$ ), which were then isolated and structurally determined by repeating the chlorination experiment at concentrations levels at least 100 times higher. The structures of 16 isolated DPs, one of which was isolated for the first time, were determined by combining mass spectrometry, using as source a matrix-assisted laser desorption/ionization and as mass analyzer a time-of-flight analyzer (MALDI-MS/TOF) and nuclear magnetic resonance (NMR) data. They were then justified by a proposed formation mechanism. Microbial growth inhibition bioassays with Escherichia coli (ATCC 25922), Klebsiella pneumoniae (ATCC 20081), and Staphylococcus aureus (ATCC 6538) were performed to determine the changes in AMO antibacterial activity. E. coli, K. pneumoniae, and S. aureus were used as indicator microorganisms in the antimicrobial assays, since these bacteria are important human pathogens with high stability against antibiotics.

\section{Materials and Methods}

\subsection{Drug and Reagents}

Amoxicillin (99.5\%) was purchased from Sigma-Aldrich (Milan, Italy). All other chemicals and solvents were purchased from Fluka (Saint-Quentin Fallavier, France) and were of HPLC grade and used as received. For the antimicrobial assessment, tryptic soy broth (TSB, Difco, Becton-Dickenson Labs) was used. All the chemicals were of analytical grade and supplied by Sigma-Aldrich. Double distilled water (Microtech) was used to prepare the dilution water and treatments. The microbial growth was measured with automatic plate reader (Synergy HTX, BioTek Instruments, Winooski, VT, USA).

\subsection{Chlorination Reaction}

\subsubsection{Apparatus and Equipment}

Column chromatography (CC) was carried out with Kieselgel 60 (230-400 mesh, Merck, Darmstadt, Germany). HPLC was performed on a Shimadzu LC-8A system using a Shimadzu SPD-10A VP UV-VIS detector (Shimadzu, Milan, Italy). Semipreparative HPLC 
was performed using an RP Gemini C18-110A preparative column (10 $\mu \mathrm{m}$ particle size, $250 \mathrm{~mm} \times 21.2 \mathrm{~mm}$ i.d., Phenomenex, Bologna, Italy) with a flow rate of $7 \mathrm{~mL} \mathrm{~min}{ }^{-1}$. The ${ }^{1} \mathrm{H}$ - and ${ }^{13} \mathrm{C}$ NMR spectra were recorded with a NMR spectrometer, operated at $400 \mathrm{MHz}$ and at $25{ }^{\circ} \mathrm{C}$ (Bruker DRX, Bruker Avance) and referenced in ppm to the residual solvent signals $\left(\mathrm{CDCl}_{3}\right.$, at $\delta_{\mathrm{H}} 7.27$ and $\left.\delta_{\mathrm{C}} 77.0\right)$. The proton-detected heteronuclear correlations were measured using a gradient heteronuclear single-quantum coherence (HSQC) experiment, optimized for ${ }^{1} \mathrm{~J}_{\mathrm{HC}}=155 \mathrm{~Hz}$, and a gradient heteronuclear multiple bond coherence (HMBC) experiment, optimized for ${ }^{\mathrm{n}} \mathrm{J}_{\mathrm{HC}}=8 \mathrm{~Hz}$. The MALDI-TOF mass spectrometric analyses were performed on a Voyager-De Pro MALDI mass spectrometer (PerSeptive Biosystems, Framingham, MA, USA). The UV/Vis spectra were recorded with a Perkin Elmer Lambda 7 spectrophotometer. The IR spectra were recorded with a Jasco FT/IR-430 instrument equipped with a single reflection ATR accessory.

\subsubsection{Chlorination Experiments}

A 10-5 M AMO solution was treated for 10 min with $10 \%$ hypochlorite (molar ratio $\mathrm{AMO} / \mathrm{NaOCl}$ 1:1 concentration, spectroscopically determined $\lambda \max 292 \mathrm{~nm}$, $\varepsilon 350 \mathrm{dm} 3 / \mathrm{mol} \mathrm{cm})$ at room temperature [37], simulating the conditions used in a typical WWTP. The experiment was repeated at $\mathrm{pH}=3$ in a common $\mathrm{H} 3 \mathrm{PO} 4 / \mathrm{KH} 2 \mathrm{PO} 4$ $(20 \mathrm{mM})$ buffer (Figure 1a), at $\mathrm{pH}=7$ in KH2PO4/K2HPO4 $(20 \mathrm{mM})$ buffer (Figure 1b) and at $\mathrm{pH}=9$ (Figure 2a). The presence of AMO was quantified using a Lambda 12 UV-Vis spectrophotometer (Perkin Elmer, 940 Winter Street, Waltham, MA 02451, USA). Absorbance peaks were determined at $230 \mathrm{~nm}$ (Figure 2b). The absorbance values were converted into concentration using a calibration curve prepared from standard solutions with known AMO concentrations. In this latter case, the $\mathrm{pH}$ of the solution, measured and recorded continuously by a $\mathrm{pH}$-meter, increased immediately from the initial $\mathrm{pH}$ of 8.0 to 10.5 , and the $\mathrm{pH}$ remained at this value during the reaction. An aliquot of the solution was taken every $5 \mathrm{~min}$, quenched by sodium thiosulphate excess, filtered, dried by lyophilization, and dissolved in a saturated sodium bicarbonate solution before being extracted with ethyl acetate. The course of the reaction was monitored by HPLC. The main degradation byproducts (DP4 and DP6-DP10 for the ethyl acetate fraction and DP1-DP3, DP5 and DP11-DP16 for the aqueous fraction; Scheme 1 and Figure 3) were identified by comparing their retention times with those of commercially available standard compounds or isolated by performing preparative experiments with an AMO solution at a concentration higher than 10-3 M treated with $5 \%$ hypochlorite at room temperature for $5 \mathrm{~min}$. The degradation byproducts obtained were isolated via column chromatography and HPLC and completely characterized using NMR and mass spectrometry (MS) analysis. DP1-DP16 were isolated in relative percentages of $1.01,0.89,2.25,2.02,1.56,1.36,2.21,2.05,3.01,2.24,1.25,1.11,1.23,1.45$, 2.25 , and $0.23 \%$, respectively. The proposed mechanism of their formation from AMO is shown in Figure 4. DP16, isolated for the first time, was determined by combining mass spectrometry (MS) and nuclear magnetic resonance (NMR) data.

\subsubsection{Chlorination Procedure and Product Isolation}

Amoxicillin $(1 \mathrm{~g}, 2.74 \mathrm{mmol})$, dissolved in milliQ water $(2 \mathrm{~L})$, was treated for $5 \mathrm{~min}$ with $5 \%$ hypochlorite (molar ratio $\mathrm{AMO} / \mathrm{NaOCl} 1: 2$; concentration spectroscopically determined at a $\lambda_{\max }$ of $292 \mathrm{~nm}, \varepsilon=350 \mathrm{dm}^{3} / \mathrm{mol} \mathrm{cm}$ ) at room temperature [38]. The $\mathrm{pH}$ of the solution increased immediately from the initial $\mathrm{pH}$ of 8.0 to 10.5 , and the $\mathrm{pH}$ remained at this value during the reaction. After $5 \mathrm{~min}$, the solution was quenched using an excess of thiosulphate, with respect to $\mathrm{NaOCl}$, and dried by lyophilization, and the residue was dissolved in a saturated $\mathrm{Na}_{2} \mathrm{CO}_{3}$ solution and extracted with ethyl acetate (EA). The EA fraction $(351 \mathrm{mg})$ was separated with the silica gel column chromatography (CC) using a gradient of methylene chloride/methanol (100:0 to 10:90, $v / v)$ to yield 15 fractions. The EA5 fraction (25 mg), eluted with methylene chloride/methanol (90:10, $v / v)$, was analyzed via HPLC using a Supelcosil LC-18 column, $25 \mathrm{~cm} \times 4.6 \mathrm{~mm}$ ID, and $5 \mu \mathrm{m}$ 
particles. The solvent system was a gradient of acetonitrile/tetrahydrofuran/water (A, 30:10:60, $v / v / v)$ and acetonitrile/water $(\mathrm{B}, 60: 40, v / v)$, starting with $0 \% \mathrm{~B}$ for $1 \mathrm{~min}$ and installing a gradient to obtain $100 \%$ B over $20 \mathrm{~min}$, at a solvent flow rate of $1.5 \mathrm{~mL} / \mathrm{min}$. The column effluent was monitored at $360 \mathrm{~nm}$. Identification of DP6 and DP4 was achieved by comparison with standard compounds. The fraction EA7 (33 mg), eluted with methylene chloride/methanol (75:25, $v / v)$, was analyzed via HPLC using a Supelcosil LC-8 column, $15 \mathrm{~cm} \times 4.6 \mathrm{~mm}$ I.D., and $5 \mu \mathrm{m}$ particles. The solvent system used was a gradient of acetic acid/methanol (A, 1:99, v/v) and acetic acid/water (B, 1:99, v/v), starting with $65 \% \mathrm{~B}$ for $1 \mathrm{~min}$ and installing a gradient to obtain $100 \%$ A over $25 \mathrm{~min}$ and returning to $65 \%$ B for $5 \mathrm{~min}$ at a solvent flow rate of $1.5 \mathrm{~mL} / \mathrm{min}$. The column effluent was monitored at $280 \mathrm{~nm}$. Identification of DP7 and DP8 was achieved by comparison with standard compounds. The fraction EA8 $(29 \mathrm{mg})$, eluted with methylene chloride/methanol (70:30, $v / v)$, was dried, dissolved in an appropriate volume of methylene chloride $(100 \mu \mathrm{L})$, and analyzed using a gas chromatograph with a flame ionization detector (Shimadzu 2010 series, Milano, Italy). The gas chromatograph was equipped with an Equity ${ }^{\mathrm{TM}}-5$ capillary column ( $30 \mathrm{~m} \times 0.25 \mathrm{~mm}$ I.D. $\times 0.25 \mu \mathrm{m}$ film thickness). The following parameters were set during the experiments: detector temperature, $340{ }^{\circ} \mathrm{C}$, carrier gas, helium $(25 \mathrm{~cm} / \mathrm{s})$, injected samples, and $1.0 \mu \mathrm{L}$, introduced into the injector using an AOC-20i auto sampler (Shimadzu, Milano, Italy) and heated to $225^{\circ} \mathrm{C}$ with a split ratio of 100:1. The initial temperature was $40^{\circ} \mathrm{C}$ with a $2 \mathrm{~min}$ hold, followed by a $8{ }^{\circ} \mathrm{C} / \mathrm{min}$ ramp to $300^{\circ} \mathrm{C}$, with a 2 min hold. Identification of DP9 and DP10 was achieved by comparison with standard compounds.
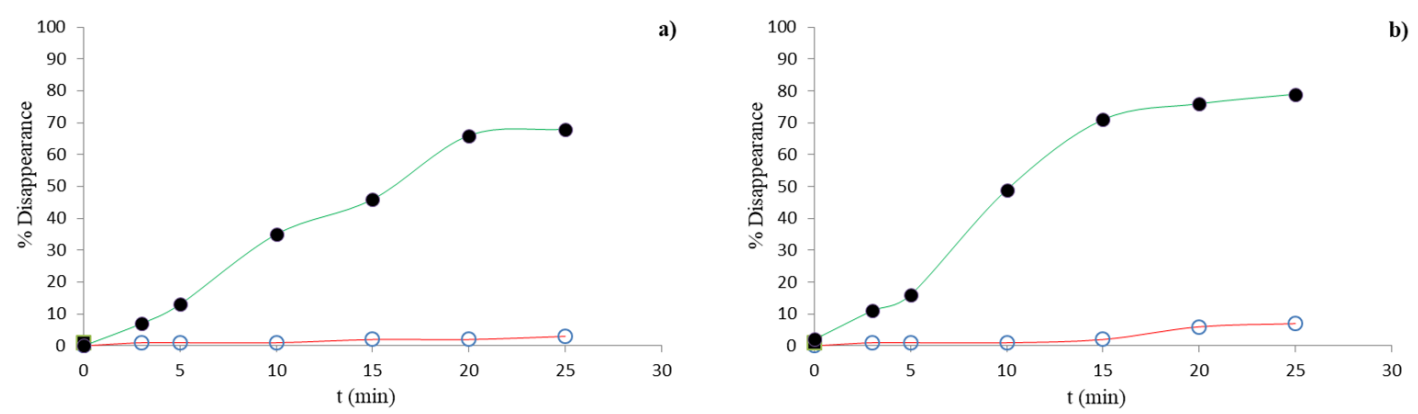

Figure 1. Time-conversion plot for the reaction of amoxicillin (AMO) with one equivalent $\mathrm{NaOCl}$ at buffered $\mathrm{pH}=3.0$ (a) and $\mathrm{pH}=7$ (b). •: AMO consumption by reaction with $\mathrm{NaOCl}$ (green); $\bigcirc$ : Disappearance of $\mathrm{AMO}$ in the absence of $\mathrm{NaOCl}(\mathrm{red})$.
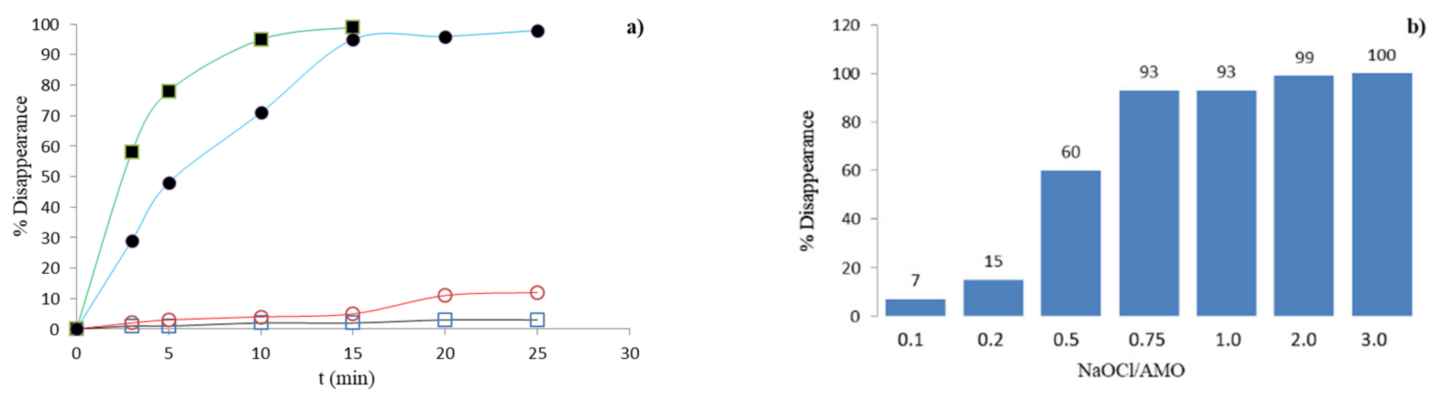

Figure 2. (a) Time-conversion plot for the reaction of $\mathrm{AMO}$ with one equivalent $\mathrm{NaOCl}$ at $\mathrm{pH}=9.0$. $\mathbf{\square}$ : $\mathrm{NaOCl}$ consumption in the presence of $\mathrm{AMO}$ (green); $\bullet$ : AMO consumption by reaction with $\mathrm{NaOCl}$ (blue); $\square$ : Disappearance of $\mathrm{NaOCl}$ in the absence of $\mathrm{AMO}$ (red); $\bigcirc$ : Disappearance of $\mathrm{AMO}$ in the absence of $\mathrm{NaOCl}$ (black); (b) AMO disappearance by $\mathrm{NaOCl}$ at $\mathrm{pH}$ basic no-buffered after a 5 min reaction. 
<smiles>CC1(C)S[C@H](NC(=O)C(N)c2ccc(O)cc2)C(=O)N1C(=O)O</smiles><smiles>N=C(C(=O)O)c1ccc(O)cc1</smiles><smiles>CC(C)CC(=O)O</smiles><smiles>CC(=O)OC(=O)CN</smiles>

Figure 3. Chemical structures of amoxicillin and its degradation byproducts.

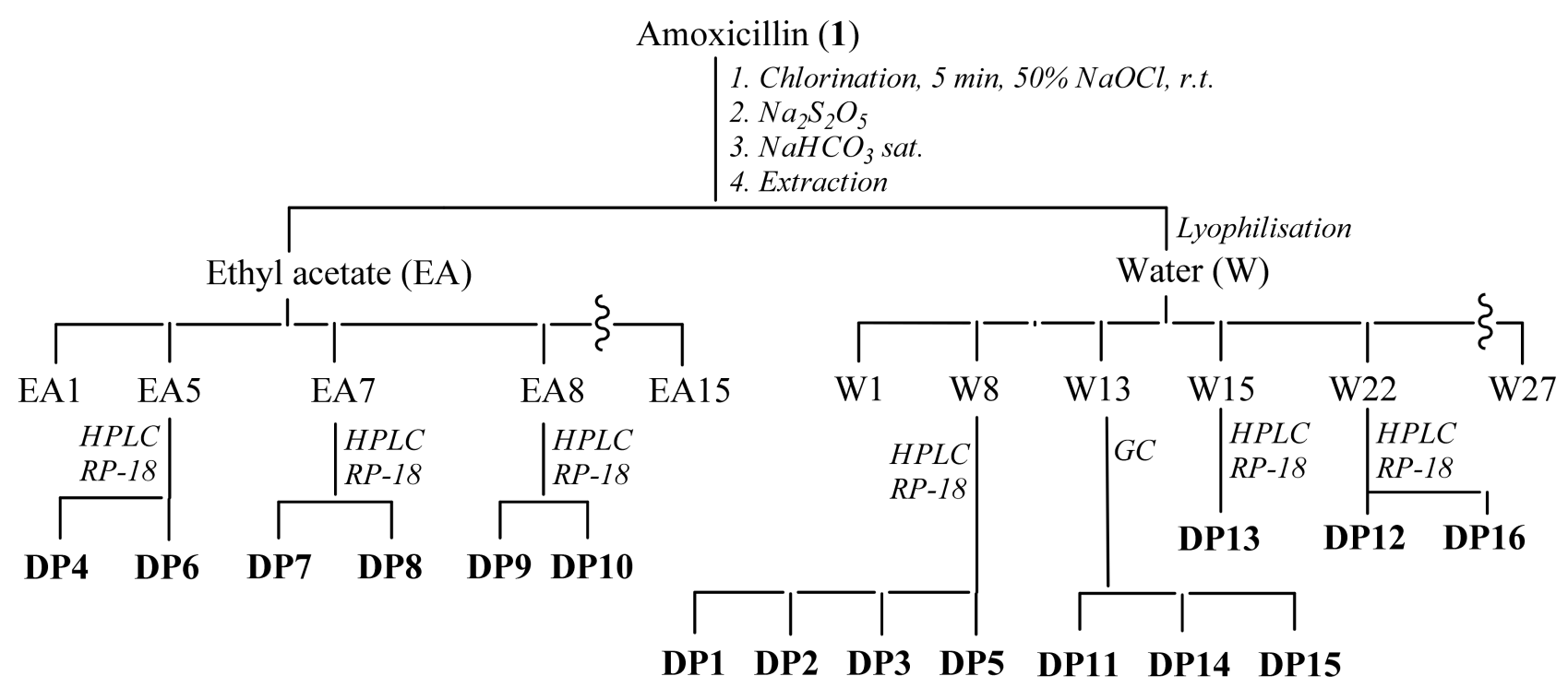

Scheme 1. Isolation of 16 identified degradation byproducts. 

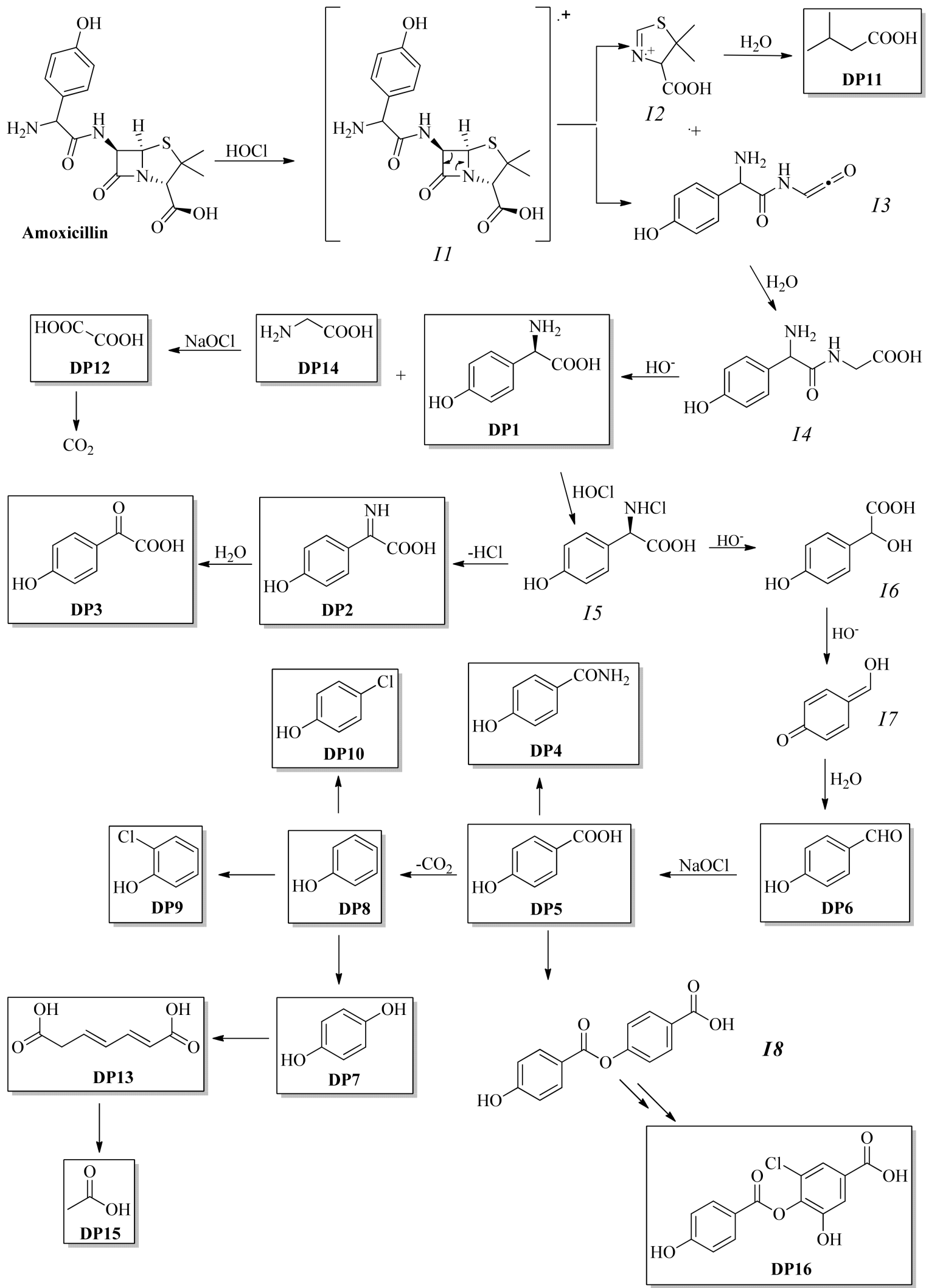

Figure 4. Plausible mechanism for the formation of DP1-DP16.

The aqueous fraction (W, $959 \mathrm{mg}$ ) was dried by lyophilization, re-dissolved in methanol, and separated with the silica gel CC using a gradient of ethyl acetate/methanol (100:0 to $0: 100, v / v)$ to yield 27 fractions. The fraction W8 $(39 \mathrm{mg})$, eluted with ethyl ac- 
etate/methanol (70:30, v/v), was analyzed via HPLC using a Discovery RP-Amide C16 column, $15 \mathrm{~cm} \times 4.6 \mathrm{~mm}$ I.D., and $5.0 \mu \mathrm{m}$ particles. The solvent system used was a mixture of $0.1 \%$ trifluoroacetic acid in acetonitrile/water (25:75), at a solvent flow rate of $1.0 \mathrm{~mL} / \mathrm{min}$. The column effluent was monitored at $254 \mathrm{~nm}$. The identification of DP1DP3 and DP5 was achieved by comparison with a standard compound. The W13 fraction (78 mg), eluted with ethyl acetate/methanol $(60: 40, v / v)$, was dried, dissolved in an appropriate volume of water/ethanol (50:50,v/v), and analyzed using a Shimadzu 2010 series GC FID (Shimadzu, Milano, Italy). The gas chromatograph was equipped with an 80/120 Carbopack ${ }^{\mathrm{TM}}$ B AW /6.6\% PEG 20M (2 m × 2 mm I.D., glass). The following parameters were set during the experiments: carrier gas, nitrogen, injected samples, and $1.0 \mu \mathrm{L}$, introduced into the injector using an AOC-20i auto sampler (Shimadzu, Milano, Italy). The initial temperature was $80^{\circ} \mathrm{C}$ with a $2 \mathrm{~min}$ hold, followed by a $4{ }^{\circ} \mathrm{C} / \mathrm{min}$ ramp to $200{ }^{\circ} \mathrm{C}$ with a 2 min hold. The identification of DP11, DP14, and DP15 was achieved by comparison with a standard compound. The fraction W15 (131 mg), eluted with ethyl acetate/methanol (50:50, v/v), was analyzed via HPLC using an octadecyl-silica ODS (2) column $(15 \mathrm{~cm} \times 4.6 \mathrm{~mm}$ I.D.). The solvent system was a mixture of acetic acid, tetrahydrofuran, methanol, and water $(1 / 2 / 10 / 87, v / v / v / v)$ at a solvent flow rate of $1.0 \mathrm{~mL} / \mathrm{min}$. The column effluent was monitored at $264 \mathrm{~nm}$. The identification of compound DP13 was achieved by comparison with a standard compound. The fraction W22 (23 mg), eluted with methanol, was analyzed via HPLC with an electron capture detector (ECD), using a $\mathrm{RP}-18$ column $(25 \mathrm{~cm} \times 4.6 \mathrm{~mm}$ ID). The solvent system used was a mixture of $25 \%$ hexadecyltrimethylammonium chloride, $\mathrm{KH}_{2} \mathrm{PO}_{4}$, water, and methanol (1:7.5:500:500, v/w/v/v) at a solvent flow rate of $1.5 \mathrm{~mL} / \mathrm{min}$. The identification of DP12 was achieved by comparison with a standard compound [39]. The structures of all the degradation byproducts are shown in Figure 3.

\subsection{Spectral Data}

DP1: (R)-2-Amino-2-(4-hydroxyphenyl)acetic acid. White powder. NMR spectra were in accordance with those reported in the literature [40].

DP2: 2-(4-Hydroxyphenyl)-2-iminoacetic acid. White powder. NMR spectra are in accordance with those reported in the literature [26].

DP3: 2-(4-Hydroxyphenyl)-2-oxoacetic acid. White powder. NMR spectra conform to those recorded for the commercially available standard.

DP4: 4-Hydroxybenzamide. White powder. NMR spectra are in accordance with those reported in the literature [41].

DP5: 4-Hydroxybenzoic acid. White powder. NMR spectra conform to those recorded for the commercially available standard.

DP6: 4-Hydroxybenzaldehyde. White oil. NMR spectra conform to those recorded for the commercially available standard.

DP7: Hydroquinone. White powder. NMR spectra conform to those recorded for the commercially available standard.

DP8: Phenol. White powder. NMR spectra conform to those recorded for the commercially available standard.

DP9: 2-Chlorophenol. White powder. NMR spectra are in accordance with those reported in the literature [42].

DP10: 4-Chlorophenol. White powder. NMR spectra are in accordance with those reported in the literature [43].

DP11: 3-Methylbutanoic acid. White powder. NMR spectra are in accordance with those reported in the literature [44].

DP12: Oxalic acid. White powder. NMR spectra conform to those recorded for the commercially available standard.

DP13: (2E,4E)-Hexa-2,4-dienedioic acid. White powder. NMR spectra conform to those recorded for the commercially available standard. 
DP14: 2-Aminoacetic acid. White powder. NMR spectra conform to those recorded for the commercially available standard.

DP15: Acetic acid. White liquid. NMR spectra conform to those recorded for the commercially available standard.

DP16: 3-Chloro-5-hydroxy-4-[(4-hydroxybenzoyl)oxy]benzoic acid. White powder. ${ }^{1} \mathrm{H}-\mathrm{NMR}\left(400 \mathrm{MHz}, \mathrm{CDCl}_{3}\right): \delta 8.13(\mathrm{~d}, \mathrm{~J}=8.0 \mathrm{~Hz}, 2 \mathrm{H}, \mathrm{H}-2, \mathrm{H}-6), 7.46(\mathrm{~d}, \mathrm{~J}=7.6 \mathrm{~Hz}, 1 \mathrm{H}$, H-6 $\left.{ }^{\prime}\right), 7.16\left(\mathrm{~d}, \mathrm{~J}=7.6 \mathrm{~Hz}, 1 \mathrm{H}, \mathrm{H}-5^{\prime}\right), 6.89$ (d, J = 8.0 Hz, 2H, H-3, H-5). ${ }^{13} \mathrm{C}-\mathrm{NMR}(100 \mathrm{MHz}$, $\left.\mathrm{CDCl}_{3}\right): \delta 128.64(\mathrm{C}-1), 131.61$ (C-1 and C-6), 115.74 (C-3 and C-5), 154.83 (C-4), 160.62 (C-7), $157.66\left(\mathrm{C}-1^{\prime}\right), 141.4\left(\mathrm{C}-2^{\prime}\right), 128.64\left(\mathrm{C}-3^{\prime}\right), 154.83\left(\mathrm{C}-4^{\prime}\right), 125.69\left(\mathrm{C}-5^{\prime}\right), 125.08\left(\mathrm{C}-6^{\prime}\right)$. ESI-MS (positive ions): $\mathrm{m} / z$ calculated for $\mathrm{C}_{13} \mathrm{H}_{8} \mathrm{Cl}_{2} \mathrm{O}_{4} \mathrm{~m} / z 297.98[\mathrm{M}]^{+}$; found $300.08[\mathrm{M}+\mathrm{H}]^{+}$, $261.52[\mathrm{M}-\mathrm{HCl}]^{+}$.

\subsection{Measurement of Antibiotic Activity}

Microbial growth inhibition tests were performed on AMO and samples were isolated from $\mathrm{NaOCl}$ experiments at initial concentrations of $5 \mathrm{mg} / \mathrm{L}$ and used E. coli (ATCC 25922), K. pneumoniae (ATCC 20081), and S. aureus (ATCC 6538) as reference strains. A preculture of bacteria was grown in tris-buffered solution (TBS) overnight at $37^{\circ} \mathrm{C}$ and then diluted with the same medium for a concentration of 103 cell $/ \mathrm{mL}$. Bacteria were inoculated into 96 wells with samples and incubated at $37^{\circ} \mathrm{C}$ for $24 \mathrm{~h}$. The growth of bacteria was evaluated by the degree of turbidity of the culture measuring the absorbance at $600 \mathrm{~nm}$.

Negative and positive controls were included in each test. Negative tests were carried out on TBS, containing $0.001 \%$ of DMSO (used with the aim of dissolving AMO) per liter of solution.

\section{Results and Discussion}

\subsection{Chlorination Experiments}

The AMO chlorination experiments were performed by mimicking the conditions of a typical WWTP, in which a $10^{-5} \mathrm{M}$ solution of the drug was treated for $10 \mathrm{~min}$ with $10 \%$ hypochlorite (AMO/hypochlorite molar ratio of 1:1; concn.) at room temperature [45-47] for different $\mathrm{pH}$ values (Figures 1 and 2).

The measurements of the AMO concentration as a function of time at the two different buffered $\mathrm{pH}$ values show how degradation was greater at $\mathrm{pH}=7$, with a percentage of about $80 \%$ after just $20-25$ min of treatment. When $\mathrm{pH}=3$, it was just under with the same time. Regardless of the $\mathrm{pH}$ value, the AMO concentration remained practically constant in the absence of $\mathrm{NaOCl}$, with a degradation percentage of no more than $5-7 \%$ at the higher $\mathrm{pH}$.

It is interesting to note that the presence of AMO practically disappeared after 15 min when it was in contact with hypochlorite. Thus, it remained almost constant in its absence. Hypochlorite, on the other hand, decomposed faster than AMO degraded, reducing by more than $95 \%$ after just 10 min, which indicates how all the active species presented in the solution contributed to drug degradation.

The measurements of the quantity of non-degraded AMO clearly shows how the percentage of degradation rapidly increased to $60 \%$ with a $\mathrm{NaOCl} / \mathrm{AMO}$ ratio of 0.5 , which was almost total with a $\mathrm{NaOCl} / \mathrm{AMO}$ ratio $=0.75$. The data reported in the literature for other emerging micropollutants generally observed longer reaction times, even in the order of hours. Oxidant concentrations even doubled that of the pollutant to ensure the complete mineralization of the latter, which was not infrequently after a double or triple treatment [44-47].

\subsection{Structure Elucidation of Degradation Byproducts DP1-DP16}

AMO chlorination-produced degradation byproducts DP1-DP16 (Figure 3) were isolated by chromatographic processes and identified on the basis of their physical features (Scheme 1). 
In $\mathrm{AMO}$ treatment with an unbuffered $\mathrm{pH}$ value, the changes of the drug were monitored with HPLC. Its main degradation byproducts (DP1-DP16, Figure 3) were identified by comparing their retention times with those of the standard compounds and by employing NMR and MS analyses. The concentrations of DP1-DP16 were at a maximum after 5 min and were in the range of 3.01-0.89\%.

The first three DPs (DP1-DP3) were $\mathrm{C}_{6} \mathrm{C}_{2}$ skeletal compounds obtained from the hydrolysis of the amide bond of the phenylethanoic acid residue and the subsequent oxidation of the alkyl chain. The DP4-DP6 had a $\mathrm{C}_{6} \mathrm{C}_{1}$ skeleton and, thus, it was easy to hypothesize that they were products derived from the decarboxylation of the previous three. Moreover, the DP7-DP10 had a $\mathrm{C}_{6} \mathrm{C}_{1}$ skeleton with an oxidized or chlorinated aromatic ring. DP11-DP15 products were di- or mono-carboxylic acids, which were final oxidation products. A separate discussion should be had for DP16, which is a phenylbenzoic ester chlorinated on the alcoholic part and clearly obtained from the esterification of two oxidation byproducts. The plausible mechanism of the DP formation from AMO is shown in Figure 4.

The reaction could start by a single-electron transfer from the lone electron pair of the amino group to $\mathrm{HClO}$, which formed the corresponding radical cation and chloride. This aminyl radical cation (I1) could undergo a $\beta$-lactam cycle when two fragments, $I 2$ and $I 3$, formed. The first fragment formed via hydrolysis and gave DP11. The I3 fragment first hydrolyzed the ketene function to a carboxylic function, giving the intermediate I4 that led to DP1 and DP14. The second fragment oxidized to DP12 and $\mathrm{CO}_{2}$. From the product DP1, it was possible to obtain DP2-DP3 with a $\mathrm{C}_{6} \mathrm{C}_{2}$ skeleton, DP4-DP6 with a $\mathrm{C}_{6} \mathrm{C}_{1}$ skeleton, and DP7-DP10 with a $\mathrm{C}_{6} \mathrm{C}_{0}$ skeleton through a series of oxidations, decarboxylations, and chlorations. Finally, DP13 and DP15 was obtained by opening the aromatic ring. A slightly different argument to justify DP16, the synthesis of which could come from the chlorination and subsequent oxidation of intermediate $I 8$, in turn was obtainable from the esterification of two DP5 molecules.

\subsection{Antibiotic Activity Data}

Figure 5 shows the antimicrobial activity of AMO and its DPs against S. aureus. Partial activity was developed at $5 \mathrm{mg} / \mathrm{L}$ AMO when the inhibition did not exceed $28 \%$ for the parent compound.

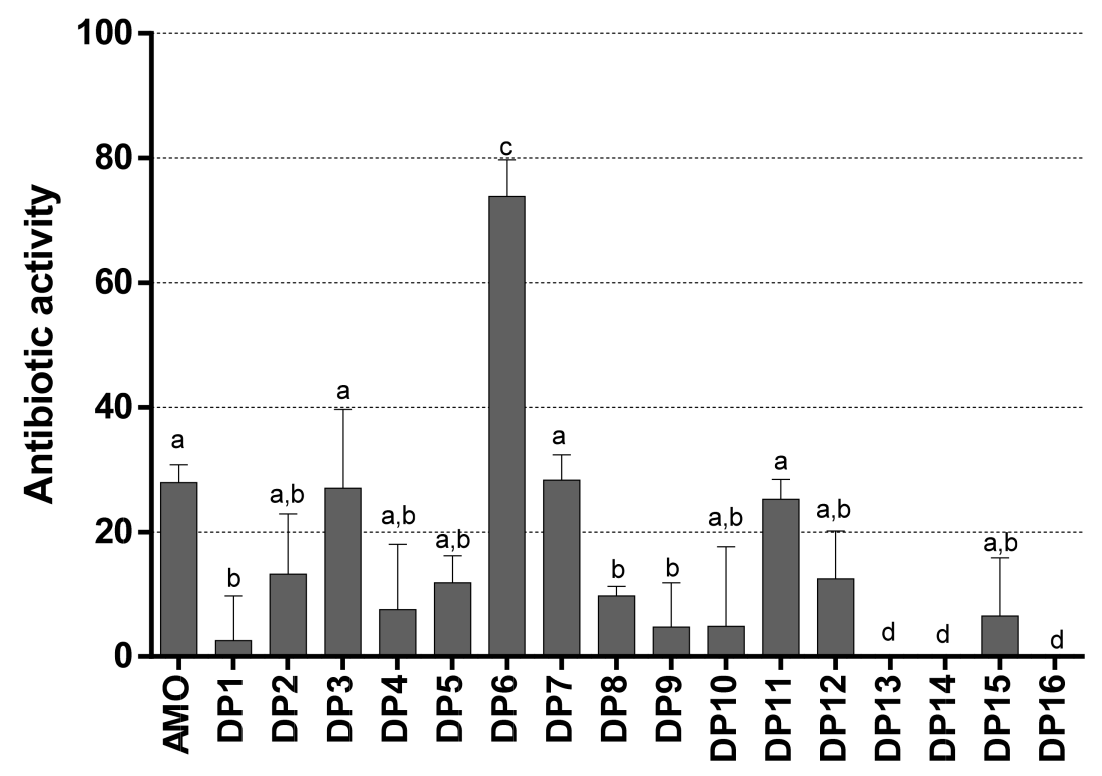

Figure 5. Antibacterial activity of AMO and its DPs against S. aureus. Groups with the same letter were not significantly different (Tukey post hoc, $p<0.05$ ). 
It was evident that $56 \%$ of DPs showed residual activity to $S$. aureus and this was more pronounced for DP6, where activity was exclusively due to oxidation byproducts with $74 \%$ of antibiotic activity. DP1, DP8, and DP9 showed decreased antibiotic activity. Only DP13, DP14, and DP16 were revealed to have no antibiotic effects.

Similar tests with E. coli and K. pneumoniae revealed that both bacteria were resistant at $5 \mathrm{mg} / \mathrm{L} \mathrm{AMO}$, with no significant antimicrobial activity (data not shown). The related DPs appeared to have no antibiotic and/or toxic effect against E. coli and K. pneumoniae (data not shown).

According to Dimitrakopoulou [48], E. coli and K. pneumoniae revealed a resistance up to $25 \mathrm{mg} / \mathrm{L} \mathrm{AMO}$, even if the suggested ranges for Minimum Inhibitory Concentrations (MICs) were 0.25-128 mg/L for Enterobacteriaceae (i.e., E. coli and K. pneumoniae) [49].

\section{Conclusions}

This paper investigated the fate of AMO by following the degradation treatment via chlorination. The reaction was carried out by simulating the conditions of a typical WWTP, using excess sodium hypochlorite at 3 different $\mathrm{pH}$ values. After the chlorination treatment, chromatographic techniques were used to isolate 16 degradation byproducts, including byproduct isolated for the first time, which were fully characterized using MS and NMR analyses and compared with parental samples. AMO underwent almost complete mineralization: $95-96 \%$ at $\mathrm{pH} 9$, almost $80 \%$ at $\mathrm{pH} 7$, and just under $70 \%$ at $\mathrm{pH} 3$ after only a few minutes of treatment. We hypothesized a possible mechanism for the degradation of $\mathrm{AMO}$ and the formation of its byproducts. The antibiotic activity of AMO depended on the test bacteria in question. With regard to E. coli and K. pneumoniae, no antimicrobial activity occurred, regardless of how low AMO concentrations were or how low transformation byproducts were. Conversely, S. aureus was less resistant to AMO, and this effect remained partially or totally in its reaction byproducts. If it was known from the literature that amoxicillin was degraded by at least 75\% in WWTPs, it was not clear what formed or the possible toxicity of the byproducts.

Author Contributions: G.L. (Giovanni Luongo) performed the chlorination experiments; M.G., A.S., G.L. (Giovanni Libralato), and L.S. performed the acute and chronic toxicity tests; A.Z., L.P., and G.D.F. designed the research study and wrote the paper. All authors have read and agreed to the published version of the manuscript.

Funding: We acknowledge AIPRAS-Onlus (Associazione Italiana per la Promozione delle Ricerche sull'Ambiente e la Salute umana) for the grants in support of this investigation.

Institutional Review Board Statement: Not applicable.

Informed Consent Statement: Not applicable.

Conflicts of Interest: The authors have no conflict of interest to declare.

\section{References}

1. Pal, A.; Gin, K.Y.-H.; Lin, A.Y.-C.; Reinhard, M. Impacts of emerging organic contaminants on freshwater resources: Review of recent occurrences, sources, fate and effects. Sci. Total Environ. 2010, 408, 6062-6069. [CrossRef] [PubMed]

2. Kasprzyk-Hordern, B.; Dinsdale, R.M.; Guwy, A.J. The occurrence of pharmaceuticals, personal care products, endocrine disruptors and illicit drugs in surface water in South Wales. Water Res. 2008, 42, 3498-3518. [CrossRef] [PubMed]

3. Gabarrón, S.; Gernjak, W.; Valero, F.; Barceló, A.; Petrovic, M.; Rodríguez-Roda, I. Evaluation of emerging contaminants in a drinking water treatment plant using electrodialysis reversal technology. J. Hazard. Mater. 2016, 309, 192-201. [CrossRef] [PubMed]

4. Huerta-Fontela, M.; Galceran, M.T.; Ventura, F. Occurrence and removal of pharmaceuticals and hormones through drinking water treatment. Water Res. 2011, 45, 1432-1442. [CrossRef]

5. Bayer, A.; Asner, R.; Schüssler, W.; Kopf, W.; Weiß, K.; Sengl, M.; Letzel, M. Behavior of sartans (antihypertensive drugs) in wastewater treatment plants, their occurrence and risk for the aquatic environment. Environ. Sci. Pollut. Res. 2014, 21, 10830-10839. [CrossRef] 
6. Boix, C.; Ibáñez, M.; Sancho, J.V.; Parsons, J.R.; de Voogt, P.; Hernández, F. Biotransformation of pharmaceuticals in surface water and during waste water treatment: Identification and occurrence of transformation products. J. Hazard. Mater. 2016, 302, 175-187. [CrossRef]

7. Mills, L.J.; Chichester, C. Review of evidence: Are endocrine-disrupting chemicals in the aquatic environment impacting fish populations? Sci. Total Environ. 2005, 343, 1-34. [CrossRef]

8. Christensen, F.M. Pharmaceuticals in the environment: A human risk? Regul. Toxicol. Pharmacol. 1998, 28, 212-221. [CrossRef]

9. Stuer-Lauridsen, F.; Birkved, M.; Hansen, L.P.; Lutzhoft, H.C.H.; Halling-Sorensen, B. Environmental risk assessment of human pharmaceuticals in Denmark after normal therapeutic use. Chemosphere 2000, 40, 783-793. [CrossRef]

10. Merlin, C.; Bonot, S.; Courtois, S.; Block, J.-C. Persistence and dissemination of the multiple-antibiotic-resistance plasmid pB10 in the microbial communities of wastewater sludge microcosms. Water Res. 2011, 45, 2897-2905. [CrossRef]

11. Andersson, D.I.; Hughes, D. Evolution of antibiotic resistance at non-lethal drug concentrations. Drug Resist. Updates 2012, 15, 162-172. [CrossRef] [PubMed]

12. Boumendjel, A.; Tawe, G.S.; Bum, E.N.; Chabrol, T.; Beney, C.; Sinniger, V.; Haudecoeur, R.; Marcourt, L.; Challal, S.; FerreiraQueiroz, E.; et al. Occurrence of the synthetic analgesic tramadol in an African medicinal plant. Angew. Chem. Int. Ed. Engl. 2013, 52, 11780-11784. [CrossRef] [PubMed]

13. Jean, J.; Perrodin, Y.; Pivot, C.; Trepo, D.; Perraud, M.; Droguet, J.; Tissot-Guerraz, F.; Locher, F. Identification and prioritization of bioaccumulable pharmaceutical substances discharged in hospital effluents. J. Environ. Manag. 2012, 103, 113-121. [CrossRef] [PubMed]

14. Fowler, P.A.; Bellingham, M.; Sinclair, K.D.; Evans, N.P.; Pocar, P.; Fischer, B.; Schaedlich, K.; Schmidt, J.-S.; Amezaga, M.R.; Bhattacharya, S.; et al. Impact of endocrine-disrupting compounds (EDCs) on female reproductive health. Mol. Cell. Endocrinol. 2012, 355, 231-239. [CrossRef] [PubMed]

15. Hess-Wilson, J.K.; Knudsen, K.E. Endocrine disrupting compounds and prostate cancer. Cancer Lett. 2006, 241, 1-12. [CrossRef] [PubMed]

16. Austin, B. Antibiotic pollution from fish farms: Effects on aquatic microflora. Microbiol. Sci. 1985, 2, $113-117$.

17. Miranda, C.D.; Castillo, G. Resistance to antibiotic and heavy metals of motile aeromonads from Chilean freshwater. Sci. Total Environ. 1998, 224, 167-176. [CrossRef]

18. Lalumera, G.M.; Calamari, D.; Galli, P.; Castiglioni, S.; Crosa, S.; Fanelli, R. Preliminary investigation on the environmental occurrence and effects of antibiotics used in aquaculture in Italy. Chemosphere 2004, 54, 661-668. [CrossRef]

19. Jones, O.A.; Voulvoulis, N.; Lester, J.N. Aquatic environmental assessment of the top 25 English prescription pharmaceuticals. Water Res. 2002, 36, 5013-5022. [CrossRef]

20. Garcia-Reiriz, A.; Damiani, P.C.; Olivieri, A.C. Different strategies for the direct determination of amoxicillin in human urine by second-order multivariate analysis of kinetic-spectrophotometric data. Talanta 2007, 71, 806-815. [CrossRef]

21. Calderon-Preciado, D.; Matamoros, V.; Bayona, J.M. Occurrence and potential crop uptake of emerging contaminants and related compounds in an agricultural irrigation network. Sci. Total Environ. 2011, 412-413, 14-19. [CrossRef] [PubMed]

22. CSTEE (Scientific Committee on Toxicity, Ecotoxicity and the Environment). Opinion on draft CPMP discussion paper on environmental risk assessment of medicinal products of human use [Non-genetically modified organism (non-GMO) containing]. In Proceedings of the 24th CSTEE Plenary Meeting, Brussels, Belgium, 12 June 2001.

23. Schreiber, F.; Szewzyk, U. Environmentally relevant concentrations of pharmaceuticals influence the initial adhesion of bacteria. Aquatic Toxicol. 2008, 87, 227-233. [CrossRef] [PubMed]

24. Andreozzi, R.; Caprio, V.; Ciniglia, C.; De Champdoré, M.; Lo Giudice, R.; Marotta, R.; Zuccato, E. Antibiotics in the environment: Occurrence in Italian STPs, fate, and preliminary assessment on algal toxicity of amoxicillin. Environ. Sci. Technol. 2004, 38, 6832-6838. [CrossRef]

25. Arslan-Alaton, I.; Dogruel, S.; Baykal, E.; Gerone, G. Combined chemical and biological oxidation of penicillin formulation effluent. J. Environ. Manag. 2004, 73, 155-163. [CrossRef] [PubMed]

26. Navalon, S.; Alvaro, M.; Garcia, H. Reaction of chlorine dioxide with emergent water pollutants: Product study of the reaction of three $\beta$-lactam antibiotics with $\mathrm{ClO}_{2}$. Water Res. 2008, 42, 1935-1942. [CrossRef]

27. Kurt, A.; Mert, B.K.; Özengin, N.; Sivrioğlu, Ö.; Yonar, T. Treatment of antibiotics in wastewater using advanced oxidation processes (AOPs). In Physico-Chemical Wastewater Treatment And Resource Recovery; IntechOpen: London, UK, 2017 ; Volume 175. [CrossRef]

28. Moles, S.; Mosteo, R.; Gómez, J.; Szpunar, J.; Gozzo, S.; Castillo, J.R.; Ormad, M.P. Towards the removal of antibiotics detected in wastewaters in the POCTEFA territory: Occurrence and $\mathrm{TiO}_{2}$ photocatalytic pilot-scale plant performance. Water 2020, $12,1453$. [CrossRef]

29. Abbassi, B.E.; Saleem, M.A.; Zytner, R.G.; Gharabaghi, B.; Rudra, R. Antibiotics in wastewater: Their degradation and effect on wastewater treatment efficiency. J. Food Agric. Environ. 2016, 14, 95-99.

30. Calisto, V.; Domingues, M.R.M.; Erny, G.L.; Esteves, V.I. Direct photodegradation of carbamazepine followed by micellar electrokinetic chromatography and mass spectrometry. Water Res. 2011, 45, 1095-1104. [CrossRef]

31. Persoone, G.; Marsalek, B.; Blinova, I.; Törökne, A.; Zarina, D.; Manusadzianas, L.; Nalecz-Jawecki, G.; Tofan, L.; Stepanova, N.; Kolar, B. A practical and user-friendly toxicity classification system with microbiotests for natural waters and wastewaters. Environ. Toxicol. 2003, 18, 395-402. [CrossRef] 
32. Romanucci, V.; Siciliano, A.; Guida, M.; Libralato, G.; Saviano, L.; Luongo, G.; Previtera, L.; Di Fabio, G.; Zarrelli, A. Disinfection by-products and ecotoxic risk associated with hypochlorite treatment of irbesartan. Sci. Total Environ. 2020, 712, 135625. [CrossRef]

33. Luongo, G.; Previtera, L.; Ladhari, A.; Di Fabio, G.; Zarrelli, A. Peracetic acid vs. sodium hypochlorite: Degradation and transformation of drugs in wastewater. Molecules 2020, 25, 2294. [CrossRef] [PubMed]

34. Luongo, G.; Guida, M.; Siciliano, A.; Libralato, G.; Saviano, L.; Amoresano, A.; Previtera, L.; Di Fabio, G.; Zarrelli, A. Oxidation of diclofenac in water by sodium hypochlorite: Identification of new degradation by-products and their ecotoxicological evaluation. J. Pharm. Biomed. Anal. 2021, 194, 113762. [CrossRef] [PubMed]

35. Chusaksri, S.; Sutthivaiyakit, S.; Sedlak, D.L.; Sutthivaiyakit, P. Reactions of phenylurea compounds with aqueous chlorine: Implications for herbicide transformation during drinking water degradation. J. Hazard. Mater. 2012, 209, 484-491. [CrossRef]

36. Sandín-España, P.; Magrans, J.O.; García-Baudín, J.M. Study of clethodim degradation and by-product formation in chlorinated water by HPLC. Chromatographia 2005, 62, 133-137. [CrossRef]

37. ISO 6341:2012. Water Quality-Determination of the Inhibition of the Mobility of Daphnia magna Straus (Cladocera, Crustacea)Acute Toxicity Test. International Organisation for Standardisation, Geneva, Switzerland. 2012. Available online: https: //www.iso.org/standard/54614.html (accessed on 23 December 2020).

38. Bedner, M.; MacCrehan, W.A. Transformation of acetaminophen bychlorination produces the toxicants 1,4-benzoquinone and $\mathrm{N}$-acetyl-p-benzoquinone imine. Environ. Sci. Technol. 2006, 40, 516-522. [CrossRef] [PubMed]

39. Hurst, J.W.; Mckim, J.M.; Martin, R.A., Jr. HPLC Determination of oxalic acid in cocoa. J. Liq. Chromatogr. 1986, 9, $2781-2789$. [CrossRef]

40. Liu, C.; Molinski, T.F. Preparation of $\alpha$-amino acids by oxidative oxazoline-oxazinone rearrangement-hydrogenation (OOOH). Scope and limitations. Chem. Asian J. 2011, 6, 2022-2027. [CrossRef] [PubMed]

41. Gowda, R.R.; Chakraborty, D. Fe-III-catalyzed synthesis of primary amides from aldehydes. Eur. J. Org. Chem. 2011, 201, 2226-2229. [CrossRef]

42. Fujita, M.; Nagai, M.; Inoue, T. Carbon-13 nuclear magnetic resonance spectral study. Effect of O-methylation of ortho-substituted phenols on the aryl carbon shielding and its application to interpretation of the spectra of some flavonoids. Chem. Pharm. Bull. 1982, 30, 1151-1156. [CrossRef]

43. Bovonsombat, P.; Ali, R.; Khan, C.; Leykajarakul, J.; Pla-on, K.; Aphimanchindakul, S.; Natchapon, P.; Nisit, T.; Anchalee, A.; Punpongjareorn, N. Facile $p$-toluenesulfonic acid-promoted para-selective monobromination and chlorination of phenol and analogues. Tetrahedron 2010, 66, 6928-6935. [CrossRef]

44. Trincado, M.; Grützmacher, H.; Vizza, F.; Bianchini, C. Domino rhodium/palladium-catalyzed dehydrogenation reactions of alcohols to acids by hydrogen transfer to inactivated alkenes. Chem. Eur. J. 2010, 16, 2751-2757. [CrossRef] [PubMed]

45. Romanucci, V.; Siciliano, A.; Galdiero, E.; Guida, M.; Luongo, G.; Liguori, R.; Di Fabio, G.; Previtera, L.; Zarrelli, A. Degradation by-products and ecotoxic risk associated with hypochlorite treatment of tramadol. Molecules 2019, 24, 693. [CrossRef] [PubMed]

46. Zarrelli, A.; Della Greca, M.; Parolisi, A.; Iesce, M.R.; Cermola, F.; Isidori, M.; Lavorgna, M.; Passananti, M.; Previtera, L. Chemical fate and genotoxic risk associated with hypochlorite treatment of nicotine. Sci. Total Environ. 2012, 426, 132-138. [CrossRef] [PubMed]

47. Zarrelli, A.; Della Greca, M.; Iesce, M.R.; Lavorgna, M.; Temussi, F.; Schiavone, L.; Criscuolo, E.; Parrella, A.; Previtera, L.; Isidori, M. Ecotoxicological evaluation of caffeine and its derivatives from a simulated chlorination step. Sci. Total Environ. 2014, 470, 453-458. [CrossRef]

48. Dimitrakopoulou, D.; Rethemiotaki, I.; Frontistis, Z.; Xekoukoulotakis, N.P.; Venieri, D.; Mantzavinos, D. Degradation, mineralization and antibiotic inactivation of amoxicillin by UV-A/ $\mathrm{TiO}_{2}$ photocatalysis. J. Environ. Manag. 2012, 98, $168-174$. [CrossRef]

49. Andrews, J.M. Determination of minimum inhibitory concentrations. J. Antimicrob. Chemother. 2001, 48, 5-16. [CrossRef] 